\title{
The Effect of Career Decisions on Entrepreneurial Intention Levels of University Students Studying Sport Sciences
}

\author{
Kadir Yildiz \\ Correspondence: Kadir Yildiz, Manisa Celal Bayar University, Faculty of Sport Sciences, Turkey. \\ Received: March 25, 2018 \\ Accepted: April 2, $2018 \quad$ Online Published: April 9, 2018 \\ doi:10.11114/jets.v6i4a.3112 \\ URL: https://doi.org/10.11114/jets.v6i4a.3112
}

\begin{abstract}
This study investigates the entrepreneurial intention levels and career decisions of a sample of 340 university students studying sport sciences. Entrepreneurship refers to a career-related choice that is driven by a risk-taking and innovation imperative. Entrepreneurs of the future are expected to make their career related choices well before they move into labor markets. In this context, this study attempts to designate young adults' entrepreneurial intentions which are considered to be highly related with their career decisions. The study also tests the potential effects of career decisions on entrepreneurial intentions. The findings of the study evidence the significant effect of conscious career choice on entrepreneurial propensity. A blind career choice is found to be also correlated with entrepreneurial intentions, albeit less so than the conscious career choice. The environmental factors subscale of career choice proves to be insignificant in terms of entrepreneurial propensity within the scope of this study's sample group. Findings are discussed with a view to practical implications.
\end{abstract}

Keywords: career decision, entrepreneurial intention, conscious career choice, university students, sport studies

\section{Introduction}

A critical element for individual and societal welfare, entrepreneurship has recently emerged as an additional resource besides the traditional production factors. Entrepreneurship represents a milestone in transition from industrial society to the information age. The concept of entrepreneurship refers to risk-oriented, proactive and innovative initiatives not only within manufacturing sector but in many different areas. Given a global, highly competitive, and innovation-oriented world context, entrepreneurship marks the new form of knowledge driven human resource. In that sense, the extent of media and political coverage, the number of books and academic research studies, events and activities and the number of so-called entrepreneurs have all been rapidly increasing. Moreover, entrepreneurship, entrepreneurial propensity, entrepreneurial intention, characteristics of an entrepreneur have become considerably popular topics and received a growing attention. Entrepreneurship has proven to be a source of added value in terms of economic development, technological improvement, emergence of new ideas, proliferation of the labor markets, and institution of income equality as well as a weapon for the fight against poverty (Börü, 2006).

Entrepreneurial intention is a function of individual variables such as achievement orientation and environmental factors such as labor market conditions. The emergence of an entrepreneur has been associated with existing career opportunities, the absence of a job, knowledge level, institutional environment, age, self-esteem and social capital among others (Baum \& Locke, 2004; Börü, 2006; Mueller \& Thomas, 2001). Defined as a combination of the desire and resolution to be self-employed, entrepreneurship is considered to be affected by psychological, environmental and sociological factors (Yockey, \& Rose, 2003).

Young adults and particularly the university students constitute the future workforce. It is hence significant to investigate their entrepreneurial intentions, the foundations of those intentions, the conditions under which entrepreneurial propensity emerges, and the imperatives that transform those attitudes into actual behavior. The topic of entrepreneurship is also a crucial part of university students' career planning to be sensitively evaluated as it incorporates the elements of effectively considering conditions and prospects (Mueller, \& Thomas 2001) and undertaking innovative-creative activities (Beugelsdijk, \& Noorderhaven, 2005).

All the above features render entrepreneurship one of the most significant topics of academic research, intellectual inquiry, and social reality. In this context, entrepreneurship is a required initiative in the field of sports such that entrepreneurs would be highly welcome in terms of enriching the sports sector with innovative and creative ideas (Geri, 
2013) and thus boosting national economy and creating societal value.

Career is conceptually defined as an embodiment of individual knowledge and skills in the form of an occupation, a kind of specialization in a specific topic, the accumulation of experience through time and a web of occupational interrelations (Redman \& Wilkinson, 2006). Career is also defined as "a succession of related jobs arranged in a hierarchy of prestige, through which persons move in an ordered" (Wilensky, 1961). Career is also considered to be "sequence of attitudes, activities or behaviours associated with work roles of individuals during the course of their lifetime" (Gerber et al., 2009). University students' early career plans significantly contribute to their future career development and employability (Akoğlan Kozak \& Dalkıranoğlu, 2013). Career decisions and the factors that affect those career plans are important topics of to be investigated on young adult samples (Bandura, Barbaranelli, Caprara \& Pastorelli, 2001). The search for a proper career and an assessment of pros and cons of potential career prospects prove to be crucial in early decision stage. Career decision process could be a well-structured journey within the framework of an overall plan whereas it could also take a relatively haphazard course of action, due to which a blind career choice emerges (Akoğlan Kozak \& Dalkıranoğlu, 2013). Career decisions could take one of those forms and career development process takes a different form based on young adults' early career expectations and decisions. Sport faculties equip young adults with domain-specific skills and competencies, and they also prepare them for entrepreneurial ventures. Although entrepreneurship has traditionally been associated with brick-and-mortar buildings and production processes, it has undergone a conceptual transformation to imply innovative ventures across different areas including the field of sport. In this context, this study investigates the relationship between career decisions and entrepreneurial intentions on a sample of sport faculty students. Specifically, the study analyzes the effect of career decisions on entrepreneurial propensity.

\section{Method}

This study is based on a correlational research design and data is collected through survey method. The questionnaire form consists of demographic questions and a set of structured questions. Participants are asked to provide their personal responses on the relevant items. All responses are provided on a 5-point Likert scale (1-Totally agree, 5-Totally disagree).

\subsection{Research Model}

Research model is shown in Figure 1. The study problematizes the hypothesized relationship between career decisions and entrepreneurial intention on a sample of 340 university students studying sport sciences. The study also tests whether career decisions predict entrepreneurial intentions of those young adults.

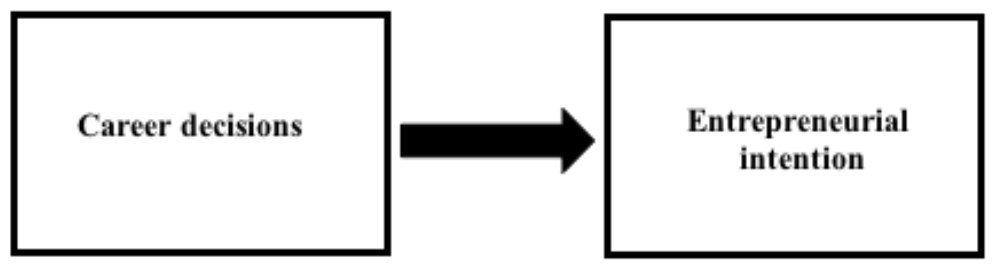

Figure 1. Research model

\subsection{Research Group}

The study group consists of 340 students (146 Female, 196 Male) studying at Manisa Celal Bayar University Faculty of Sport Sciences and the sample was recruited through convenience sampling method.

\subsection{Data Collection Tools}

Entrepreneurship scale. The scale was developed by Y1lmaz and Sümbül (2009) on sample of university students. The scale consists of 36 items and an overall score is calculated for the total scale. Sample items include "I am able to create different choices in tough situations", "I do not have any reservations in taking risks", and "I am able to foresee the future and be prepared in advance".

Career decisions scale. The scale was developed by Yusupu (2015) on a university student sample. The 30-item career decisions scale consists of three subscales, namely conscious career choice, blind career choice and environmental factors. Conscious career choice refers to an informed form of career path adopted through a facultative process. A blind career choice implies a lack of informed decision-making characterized by limited time, hastiness, and immaturity. A blind career choice involves indecisiveness and discontent. Lastly, environmental factors refer to the mismatch between an individual's desires and family wishes. Sample items include "I am able to acquire new skills to be successful in my career", and "I believe that I will be successful in my career" for conscious career choice subscale; "I am not sure 
whether I like my current job or not", and "I still do not know my future career prospects" for blind career choice; and finally, "I chose this career because of my family, thus I am not very much interested in my current studies", and "My career decision is based on pure chance" for environmental factors subscale.

Reliability coefficients. Internal reliability coefficients were calculated to confirm scale reliabilities. A Cronbach's alpha value greater than and equal to 0,90 is considered to represent excellent reliability and a value between 0,80 and 0,90 represents a good internal consistency (Yildiz, \& Dirik, 2017; Hair, Black, Babin, \& Anderson, 2010). The Cronbach's alpha reliability scores for the scales of this study are $\alpha=0,97, \alpha=0,92, \alpha=0,89$ and $\alpha=0,84$ for entrepreneurial intention, conscious career choice, blind career choice and environmental factors respectively. These findings provide evidence for reliability of the scales of the current study.

\subsection{Statistical Analysis of Data}

All data were analyzed through IBM SPSS Statistics 21,0 software package program. The data fulfill the homogeneity of variance and normality assumption given a cut-off value between -3 and +3 for skewness and kurtosis (Byrne, 2010).

The construct validity of the scales was tested through confirmatory factor analysis with IBM SPSS Amos software package program. Following Kline's (2010) recommendations, the chi-squared test, the root mean square error of approximation (RMSEA), the comparative fit index (CFI), and the standardized root mean square residual (SRMR) values are investigated. According to Byrne (2010), the acceptable cut-off values for CFI, GFI and TLI are $>0,90$, and for RMSEA values less than 0,05 indicate good fit. Hu and Bentler (1998) recommends a cut-off value close to 0,08 for SRMR. A chi-square index value less than 5 represents acceptable fit (Klein, 2010). In this study study, the fit indices for the overall CFA are X2/df $=2,35 ; \mathrm{GFI}=0,90 ; \mathrm{CFI}=0,97 ; \mathrm{TLI}=0,97$; $\mathrm{RMSEA}=0,05$, and $\mathrm{SRMR}=0,05$.

\section{Findings}

Table 1 demonstrates the descriptive statistics pertaining to the study group. According to descriptive statistics, 42,9\% of the participants are women $(n=146)$ and $57,1 \%$ are men $(n=194) .21,8 \%$ of the participants report their fathers to work in public sector, $28,8 \%$ in private sector, $20,6 \%$ to be self-employed and $28,8 \%$ to be retired. $14,1 \%$ of the participants state their mothers to be public sector employees, $37,6 \%$ to be private sector employees, $19,4 \%$ to be self-employed, and $28,8 \%$ to be retired. $12,9 \%$ of the participants are freshmen; $20 \%$ are sophomores; $20 \%$ are junior, and $47,1 \%$ are senior students. $60,6 \%$ of the participants attend daytime classes, and $39,4 \%$ attend evening classes. Finally, $64,1 \%$ of the participants respond positively to the question on whether they have an entrepreneurial intention as part of their future career plans.

Table 1. Descriptive statistics

\begin{tabular}{|c|c|c|c|c|c|c|c|c|}
\hline Variables & & $\mathrm{f}$ & $\%$ & Total & $X$ & $\mathrm{Sd}$ & Min. & Max. \\
\hline \multirow{2}{*}{ Gender } & Woman & 146 & 42.9 & \multirow{3}{*}{340} & & & & \\
\hline & Man & 194 & 57.1 & & & & & \\
\hline \multirow{5}{*}{ Father's job } & Public & 74 & 21.8 & & & & & \\
\hline & Private & 98 & 28.8 & \multirow{3}{*}{340} & & & & \\
\hline & Self-employed & 70 & 20.6 & & & & & \\
\hline & Retired & 98 & 28.8 & & & & & \\
\hline & Public & 48 & 14.1 & \multirow{4}{*}{340} & & & & \\
\hline \multirow{3}{*}{ Mother's job } & Private & 128 & 37.6 & & & & & \\
\hline & Self-employed & 66 & 19.4 & & & & & \\
\hline & Retired & 98 & 28.8 & & & & & \\
\hline \multirow{4}{*}{ Degree } & Freshman & 44 & 12.9 & \multirow{4}{*}{340} & & & & \\
\hline & Sophomore & 68 & 20.0 & & & & & \\
\hline & Junior & 68 & 20.0 & & & & & \\
\hline & Senior & 160 & 47.1 & & & & & \\
\hline \multirow{2}{*}{ Daytime/evening studying } & Daytime & 206 & 60.6 & \multirow{2}{*}{340} & & & & \\
\hline & Evening & 134 & 39.4 & & & & & \\
\hline \multirow{4}{*}{$\begin{array}{l}\text { Entrepreneurial intention in } \\
\text { career planning } \\
\text { Age } \\
\text { Family income }\end{array}$} & Yes & 218 & 64.1 & \multirow{2}{*}{340} & & & & \\
\hline & No & 122 & 35.9 & & & & & \\
\hline & & & & & 21.64 & 1.96 & 18 & 31 \\
\hline & & & & 340 & 4757 & 1410 & 1410 & 9000 \\
\hline
\end{tabular}

Participants were asked to state whether their future career planning includes an entrepreneurial venture, and their responses were subjected to independent samples t-test to determine potential mean score differences. Table 2 displays the results of t-test analysis. 
Table 2. T-test results comparing scale mean scores based on the question, "Do you have an intention to start your own business as part of your career planning?"

\begin{tabular}{lllllll}
\hline $\mathrm{N}=340$ & Group & $\mathrm{N}$ & Mean & SD & $\mathrm{t}$ & $\mathrm{p}$ \\
\hline \multirow{2}{*}{ Entrepreneurial intention } & Yes & 218 & 4.27 & 0.47 & \multirow{2}{*}{13.154} & \multirow{2}{*}{$0.00^{*}$} \\
& No & 122 & 3.38 & 0.76 & & \\
\hline \multirow{2}{*}{ Conscious career choice } & Yes & 218 & 4.03 & 0.50 & \multirow{2}{*}{12.290} & \multirow{2}{*}{$0.00^{*}$} \\
\hline \multirow{2}{*}{ Blind career choice } & No & 122 & 3.17 & 0.78 & & \multirow{2}{*}{0.60} \\
& Yes & 218 & 2.55 & 0.83 & \multirow{2}{*}{0.513} & \multirow{2}{*}{0.31} \\
\hline \multirow{2}{*}{ Environmental factors } & No & 122 & 2.50 & 0.91 & \multirow{2}{*}{0.011} & \multirow{2}{*}{0.35} \\
\end{tabular}

$* \mathrm{p}>0.05$

According to the t-test findings, participants who have an intention to start their own business as part of their career plans report significantly higher levels entrepreneurial intention $(x=4,27)$ as well as higher levels of conscious career choice $(\mathrm{x}=4,03)$ as compared to those that do not have entrepreneurial career plans $(\mathrm{p}<0.05)$.

Table 3. Correlations between research variables

\begin{tabular}{llllll}
\hline Variables $(\mathrm{N}=340)$ & Mean & $\mathrm{SD}$ & 1 & 2 & 3 \\
\hline 1. Entrepreneurial intention & 3.95 & 0.73 & $(0.97)$ & & \\
2. Conscious career choice & 3.72 & 0.74 & $0.61 * *$ & $(0.92)$ & \\
3. Blind career choice & 2.53 & 0.86 & $0.14 * *$ & $0.14 * *$ & $(0.89)$ \\
4. Environmental factors & 2.37 & 0.93 & 0.09 & 0.01 & $0.84 * *(0.84)$ \\
\hline
\end{tabular}

$* * \mathrm{p}<0,01$, Values in parentheses represent Cronbach's alpha reliability coefficients.

Mean scores, standard deviations and correlations among research variables are shown in Table 3 . There is a statistically significant, positive and moderate correlation between entrepreneurial intention and conscious career choice ( $\mathrm{r}=0,61$, $\mathrm{p}<0,05)$; and a statistically significant and low correlation between entrepreneurial intention and blind career choice $(\mathrm{r}=0,14, \mathrm{p}<0,05)$. Additionally, there is a significantly positive and high correlation between blind career choice and environmental factors $(r=0,840, p<0,05)$. Findings show that entrepreneurial intentions tend to increase particularly in the presence of a conscious career choice.

Regression analysis investigating the effect of career decisions on entrepreneurial intention levels of the participants is shown in Table 4.

Table 4. Regression analysis

\begin{tabular}{lllllllll}
\hline Dependent Variable & Independent variables & $\beta$ & $\mathrm{t}$ & $\mathrm{p}$ & $\mathrm{F}$ & Model $(\mathrm{p})$ & $\mathrm{R}$ & $\mathrm{R}^{2}$ \\
\hline \multirow{4}{*}{ Entrepreneurial intention } & Constant & & 8.54 & 0.00 & 70.983 & 0.000 & 0.623 & 0.388 \\
& Conscious career choice & 0.62 & 14.12 & 0.00 & & & & \\
& Blind career choice & -0.04 & -0.56 & 0.57 & & & & \\
& Environmental factors & 0.12 & 1.59 & 0.11 & & & & \\
\hline
\end{tabular}

$\mathrm{N}=340$, Beta values represent standardized $\beta$ coefficients.

According to the linear regression model, conscious career choice is a statistically significant predictor of entrepreneurial intention $(\beta=0,62, p<0,00)$ and it accounts for $38 \%$ of the variance explained of participants' overall entrepreneurial intentions.

\section{Discussion and Conclusion}

Entrepreneurs provide the society with goods and services from the most basic to the most sophisticated, form the foundation of production and provide the leading source of employment, and significantly contribute to the growth of national economy by supporting value-creation activities. Given the significance of entrepreneurship for individual and societal progress, it could be regarded as a critical tool and opportunity in early career decisions of young adults. Thanks to the rapid dissemination of information among young people as a byproduct of developing technology and information society, university students are immediately aware of any developments on an almost global scale. This reality is a double-edged sword, such that it creates both opportunities and threats for employability prospects. The emerging innovations and the substitution of various production factors such as human muscle strength and unskilled human resource, and replacement by technology of previously manual tasks cause contraction of public and private sector employment. Entrepreneurship thus becomes an increasingly important career choice for university students. This career related paradigm shift could contribute to young adults' entrepreneurial propensity. As in many other sectors, the 
entrepreneurial intentions of sport students pose a significant potential for individual and societal development.

According to the findings of the empirical study, the participants of the current study who are reported to have a conscious career choice are more likely to have entrepreneurial intentions. There is a linear increase in sport faculty students' conscious career choice and entrepreneurial intentions. The sport faculty students' career consciousness is thereby documented with a view to entrepreneurial tendencies. In other words, young adults are attracted to this relatively new form of employability, that is entrepreneurship, as a way out of and escape from possible unemployment. The concept of career encompasses all individual attempts that a person engages in such as adaptiveness, self-improvement and advancement (Akoğlan Kozak, \& Dalkıranoğlu, 2013). Given the contemporary developments and labor market conditions, the concept of a career and relevant decisions have been transformed to increasingly cover the concept of entrepreneurship.

In defining the characteristics of an entrepreneur, Morris, Kuratko \& Schindehutte (2001) emphasize the significance of concepts such as utilizing opportunities, acquiring resources, hard work, optimism, risk-taking and leadership. Universities are expected to offer young adults a plethora of career opportunities and guide them in managing an entrepreneurial career path. The current study reinforces the findings of previous studies that provide evidence for the link between career decisions and entrepreneurial processes (Allahverdi, 2006; Saffari, Tojari, Khodayari, Mohammadi, \& Khalifa, 2013; Timmons, 1985; Timmons, \& Spinelli, 2008).

As a result of this study offers a number of implications and recommendations. First, universities should provide career development and consulting services to young adults throughout their scholarly education. Second, young adults could be well-informed as to their future employability choices with a particular view to entrepreneurial possibilities and best examples. Third, young adults should be motivated to think out of the box and see beyond the public-private employment dichotomy. The findings of the study point to the need for student-centered and non-traditional practices that better prepare students for the future work life characterized by technology-driven innovations. Universities are especially obliged to manage and facilitate career processes of students and manage potential career crises given the high figures of unemployed young people and unemployment problem.

\section{References}

Akoğlan, K. M., \& Dalkıranoğlu, T. (2013). Career perceptions of new graduates: Anadolu University example. Anadolu University, Journal of Social Sciences, 13(1), 41-52.

Allahverdi, N. (2006). Studying the practicality of reliability, validity and criteria of entrepreneurship measuring scale among teachers in education in Tehran. AM thesis, Psychometrics in Tehran Azad University Central Branch.

Bandura, A., Barbaranelli, C., Caprara, G. V., \& Pastorelli, C. (2001). Self efficacy beliefs as shapers of children's aspirations and career trajectories. Child Development, 72(1), 187-206. https://doi.org/10.1111/1467-8624.00273

Baum, J. R., \& Locke, E. A. (2004). The relationship of entrepreneurial traits, skill, and motivation to subsequent venture growth. Journal of Applied Psychology, 89(4), 587. https://doi.org/10.1037/0021-9010.89.4.587

Beugelsdijk, S., \& Noorderhaven, N. (2005). Personality characteristics of self-employed; an empirical study. Small Business Economics, 24(2), 159-167. https://doi.org/10.1007/s11187-003-3806-3

Börü, D. (2006). Girişimcilik eğilimi: Marmara üniversitesi işletme bölümü öğrencileri üzerine bir araştırma. Marmara Üniversitesi Yayın No: 733. İstanbul: Sosyal Bilimler Enstitüsü Yayın No: 21.

Byrne, B. M. (2010). Structural equation modeling with AMOS. Basic concepts, applications, and programming (2nd ed.). New York, NY: Routledge Academic.

Gerber, M., Wittekind, A., Grote, G., \& Staffelbach, B. (2009). Exploring types of career orientation: A latent class analysis approach. Journal of Vocational Behavior, 75(3), 303-318. https://doi.org/10.1016/j.jvb.2009.04.003

Geri, S. (2013). Research on Entrepreneurial Characteristics of Students in School of Physical Education and Sports. Turkish Journal of Education, 2(3), 50-60. https://doi.org/10.19128/turje.181064

Hair, J. F., Black, W. C., Babin, B. J., \& Anderson, R. E. (2010). Multivariate Data Analysis, (7th ed). Upper Saddle River, NJ: Prentice Hall.

Hu, L., \& Bentler, P. M. (1998). Fit indices in covariance structure analysis: Sensitivity to underparameterized model misspecification. Psychological Methods, 3(4), 424-453. https://doi.org/10.1037//1082-989X.3.4.424

Kline, R. B. (2010). Principles and practice of structural equation modeling (3rd ed.). New York, New York: Guilford Press.

Morris, M. H., Kuratko, D. F., \& Schindehutte, M. (2001). Towards integration: understanding entrepreneurship through frameworks. The international journal of entrepreneurship and innovation, 2(1), 35-49. 
https://doi.org/10.5367/000000001101298765

Mueller, L. S., \& Thomas, S. A. (2001). Culture and entrepreneurial potential: A nine country study of locus of control and innovativeness. Journal of Business Venturing, 16, 51- 75. https://doi.org/10.1016/S0883-9026(99)00039-7

Redman, T., \& Wilkinson, A. (2006). Contemporary human resource management, text and cases. NewYork: Financial Times Prentice Hall.

Saffari, L., Tojari, F., Khodayari, A., Mohammadi, S., \& Khalifa, S. N. (2013). Determining the validity and reliability of measuring scale for entrepreneurship in sport. Archives of Applied Science Research, 5(1), 289-294.

Timmons, J. (1985). New venture creation. Second Edition. Homewood, IL: Richard D. Irwin, Inc.

Timmons, J. A., \& Spinelli, S. (2008). New venture creation entrepreneurship for the $21^{\text {st }}$ century. Eight Edition. Colombus: McGraw-Hill.

Wilensky, H. L. (1961). Careers, lifestyles, and social integration. International Social Science Journal, 12(4), 553-558.

Yildiz, H., \& Dirik, D. (2017). Management innovation to contextual performance: The mediating role of job satisfaction. In: Hasan Arslan, Mehmet Ali İçbay, Rasim Yılmaz, Günther Löschnigg, (Eds.), Recent studies in economics (pp. 253-263). ISBN: 978-839-439-633-6.

Yilmaz, E., \& Sünbül, A. M. (2009). Developing scale of university students entrepreneurship. Selçuk University The Journal of Institute of Social Sciences, 21, 195-203. http://dergisosyalbil.selcuk.edu.tr/susbed/article/view/318.

Yockey, M. D., \& Rose, J. W. (2003). Entrepreneurial propensity: Componenets and measurements. https://fusionmx.babson.edu/entrep/fer/Babson2002/III/III_S9/III_S9.htm. Erişim Tarihi: 13.03.2018

Yusupu, R. (2015). Relationships between career decisions, perfectionism, learning morivation and academic success among universtiry students. Master Thesis. Dokuz Eylül University, Institute of Educational Sciences, İzmir.

\section{Copyrights}

Copyright for this article is retained by the author(s), with first publication rights granted to the journal.

This is an open-access article distributed under the terms and conditions of the Creative Commons Attribution license which permits unrestricted use, distribution, and reproduction in any medium, provided the original work is properly cited. 